\title{
Fire Extinguishing Time by Sprinkler
}

\author{
JUZO UNOKI \\ Nohmi Bosai Kogyo Co., Ltd. \\ 4-7-3, Kudan-Minami, Chiyoda-ku, Tokyo 102, Japan
}

\section{ABSTRACT}

Sprinkler actuation time has been calculated for various cases, but there has been 1ittle study on extinguishing time after sprinkler actuation. Therefore, we have tried to draw an equation for the prediction of extinguishing time in the compartment fires where the ceiling is not high, and burning rate and water discharge rate are comparatively low. It is considered that the fire extinguishing performance depends on the interaction of sprinkler sprays with buoyant plumes, and cooling effect on a fire source by water discharge. The ratio of the updraft gas velocity in the plume to the velocity of water drops is considered as the former factor, and the ratio of the burning rate to the water discharge rate as the latter. We have obtained a generalized equation for the extinguishing time after sprinkler actuation by dimensional analysis, using these factors. We also attempted numerical calculation of extinguishing time for an example by this equation. This is the case of a crib fire with a constant burning rate. We consider that the extinguishing time for sprinklers will become one of the important factors on extinguishing performance of sprinklers.

\section{INTRODUCTION}

Calculations of the time it takes for sprinklers to operate after their detection of fires occurring in compartments have been made for various cases [1], [2]. However, there have been published very few generalized equations for the prediction of time from actuation of sprinklers to extinguishment of the fires. In this paper we assumed fires in compartments of residential buildings and obtained an equation for the prediction of extinguishing time by dimensional analysis and determined constants by experiment for the case that the ceiling is not high, burning rate and water discharge rate are comparativeIy low. We also attempted numerical calculations of extinguishing time for a certain case, using the equations.

\section{EQUATIONS FOR THE PREDICTION OF EXTINGUTSHING TIME}

It is considered that the fire extinguishing effectiveness of sprinklers depends on the following conditions.

1. To what extent spray water drops can penetrate through the updraft of the fire source. 
2. At what discharge rate water must be delivered to the fire source in order to suppress heat generation from the fire source and to stop continued combustion.

As a dimensionless factor which governs the condition 1., the ratio of the updraft gas velocity in the plume, Up, to the velocity of water drops, Ut, is considered where the interaction between the fire plume and spray water drops is mainly governed by gravity because of comparatively low water discharge pressure [3]. As a dimensionless factor governing the condition 2., the ratio of the mass burning rate at the start of water discharge, $Q$, to the water discharge rate onto the upper surface of the fuel (in the case of no updraft of the gas), Qw, is considered [4]. On the other hand, as a dimensionless factor indicating the fire extinguishing effectiveness, the ratio of the time from the sprinkler actuation to the fire extinguishment, $T$, to the time from the outbreak of fire to the sprinkler actuation, To, is considered. Hence, the following relation is established among these dimensionless factors.

$T / T_{o}=f(U p / U t, Q / Q w)$

The maximum gas velocity of the updraft in the plume, Upm, is expressed by the following equation [2].

$\frac{\mathrm{Upm}}{\sqrt{\mathrm{gH}}}=3.16 \frac{\dot{\mathrm{Q}}^{1 / 3}}{\mathrm{H}^{5 / 6}}\left[\mathrm{Cp} \gamma_{0} \text { to } \mathrm{g}^{1 / 2}\right]^{-1 / 3}$

where

H : distance from upper surface of crib to ceiling

$\dot{0}:$ heat release rate from fuel

Cp: isopiestic specific heat of air

ro: density of air under standard ambient condition $\left(20^{\circ} \mathrm{C}, 1\right.$ atm. $)$

to: temperature of air under standard ambient condition $\left(20^{\circ} \mathrm{C}, 1 \mathrm{~atm}.\right)$

g : gravitational acceleration

Since there would not be substantial change in diameter and velocity of the plume extending from the upper surface of the fuel to the ceiling, whole Up may be represented by Upm. The heat release rate from the fuel is calculated from $\dot{Q}=\mathrm{Qh}$, where $\mathrm{h}$ is the heat release rate per unit weight of the fuel and $\mathrm{Q}$ is the mass burning rate of the fuel. Consequent1y

Up $\propto\left(\frac{Q}{H} \cdot \frac{h g}{C_{p} \gamma_{0} \text { to }}\right)^{2 / 3}$

Water drops having radius of approximately $2 \times 10^{-2} \mathrm{~cm}$ or larger and falling in the air are subjected to resistance as defined by Newton's law, and their velocity, Ut, is expressed by the following equation [5].

$U t=2.11 \sqrt{\frac{g(\gamma w-\gamma)}{\gamma}} \sqrt{\frac{d}{2}}$

where

$\gamma_{\mathrm{w}}$ : density of water

$\gamma$ : density of gas in plume

d : diameter of spray drop 
Since $\gamma$ is very small compared to $\gamma \mathrm{w}, \gamma \mathrm{w} / \gamma$ may be used in 1 leu of $\left(\gamma \mathrm{w}^{-\gamma} \gamma / \gamma\right.$. If sprinkler models are specified, distribution of spray drop diameters is characterized for each sprinkler mode1, and therefore the mean diameter of the drops, $\mathrm{dM}$, may be used in lieu of $\mathrm{d}$. Accordingly

Ut $\propto\left(\frac{g \gamma w d M}{\gamma}\right)^{1 / 2}$

From the equations (3) and (5)

$\frac{\mathrm{Up}}{\mathrm{Ut}} \propto\left(\frac{\mathrm{h}}{\mathrm{Cp} \gamma_{0} \text { to } \gamma_{\mathrm{W}^{3 / 2}} \mathrm{~g}^{1 / 2}}\right)^{1 / 3}\left(\frac{\mathrm{Q}}{\mathrm{H}}\right)^{1 / \mathrm{a}}\left(\frac{\gamma}{\mathrm{dM}}\right)^{1 / 2}$

From the equations (1) and (6)

$\frac{T}{\text { To }}=k\left(\frac{Q}{Q W}\right)^{\mathrm{m}}\left[\mathrm{A} \cdot \frac{\mathrm{Q}}{\mathrm{H}} \cdot\left(\frac{\gamma}{\mathrm{dM}}\right)^{3 / 2}\right]^{\ell / 3}$

Where

$A=\frac{h}{\text { Cp } \gamma_{0} \text { to } \gamma w^{3 / 2} g^{1 / 2}}$

With $\ell / 3=n$, the above equation becomes:

$\frac{T}{T o}=k\left(\frac{Q}{Q W}\right)^{\mathrm{m}}\left[A \cdot \frac{Q}{H} \cdot\left(\frac{\gamma}{d M}\right)^{s / 2}\right]^{n}$

Then, values for $k, m$ and $n$ are obtained by experiment.

\section{EXPERIMENTS AND RESULTS}

As shown in FTGURE 1 three sprinkler heads were installed on the ceiling with a height of $3.5 \mathrm{~m}$. They were arranged with the distance from the fire source, L, varied, so that water drops may fall upon the fire source at different delivery rates. For the fire source, cribs of cedar wood sticks, each sized

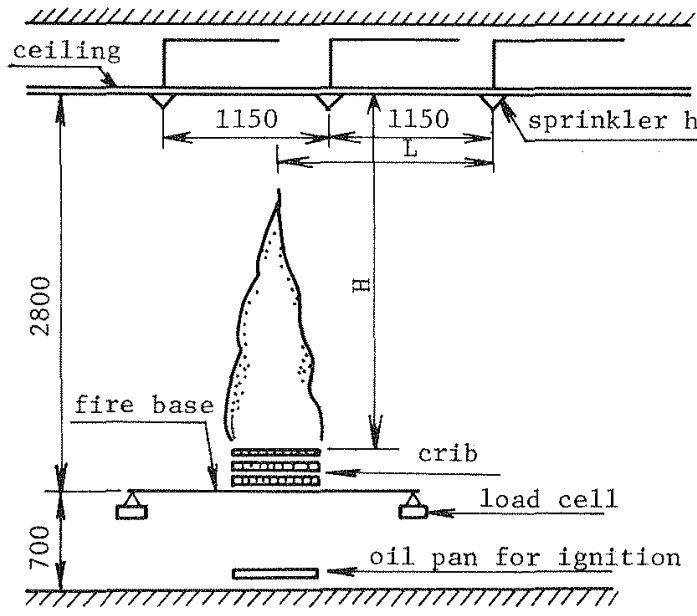

FIGURE 1 Arrangement of fire extinguishing experiment

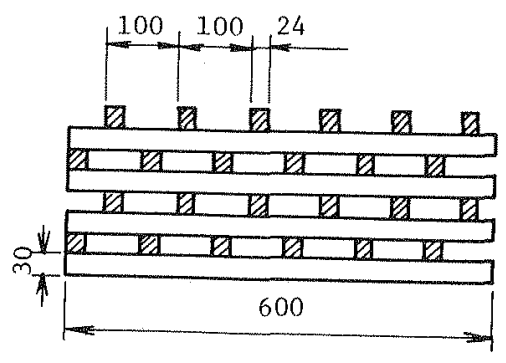

FIGURE 2 Crib (example in the case of 8 layers) 
$24 \mathrm{~mm} \times 30 \mathrm{~mm} \times 600 \mathrm{~mm}$ with moisture content of $9 \sim 12 \%$ and stacked in six, eight and ten layexs as shown in FIGURE 2 were used. To ignite them an oil pan (60cm $\mathrm{x} 60 \mathrm{~cm}$ ) containing $600 \mathrm{cc}$ of gasoline was placed under the crib. It was removed from the position in one minute after ignition. Water discharge was started when the wood cribs showed a weight loss by $30 \%$, but the burning rates from the ignition to water discharge $(60,90,130 \mathrm{kcal} / \mathrm{s})$ were considered to be almost constant because of ignition by an oil pan (heat release rate:190 kcal/s). Disappearance of flame on the crib was regarded as conclusion of extinguishment. TABLE 1 shows measured values in the experiments.

TABLE 1. Result of extinguishing test with sprinklers

\begin{tabular}{|c|c|c|c|c|c|c|c|c|}
\hline Test & No. & $\begin{array}{l}\text { Weight } \\
\text { of } \\
\text { crib }\end{array}$ & $\begin{array}{l}\text { Time from } \\
\text { ignition } \\
\text { to water } \\
\text { dis- } \\
\text { charge }\end{array}$ & $\begin{array}{l}\text { Time from } \\
\text { water } \\
\text { discharge } \\
\text { to extin- } \\
\text { guishment }\end{array}$ & $\begin{array}{l}\text { Water } \\
\text { dis-- } \\
\text { charge } \\
\text { rate on } \\
\text { crib }\end{array}$ & $\begin{array}{l}\text { Mass burn- } \\
\text { ing rate } \\
\text { just be- } \\
\text { fore water } \\
\text { discharge }\end{array}$ & $\begin{array}{l}\text { Distance } \\
\text { from upper } \\
\text { surface } \\
\text { of crib to } \\
\text { ceiling }\end{array}$ & $\begin{array}{l}\text { Density } \\
\text { of air } \\
\text { in plume }\end{array}$ \\
\hline Group & No. & $\begin{array}{l}W \\
(\mathrm{~kg})\end{array}$ & $\begin{array}{c}\text { To } \\
\text { (min.) }\end{array}$ & $\frac{T}{(\min .)}$ & $\left(\begin{array}{c}\text { OW } \\
\left(\mathrm{kg} / \mathrm{min}^{2}\right. \\
\left.0.36 \mathrm{~m}^{2}\right)\end{array}\right.$ & $\begin{array}{c}\mathrm{Q}=0.3 \mathrm{~W} / \mathrm{To} \\
(\mathrm{kg} / \mathrm{min} .)\end{array}$ & $\underset{(m)}{H}$ & $\left(\mathrm{~kg} / \mathrm{m}^{3}\right)$ \\
\hline A & $\begin{array}{l}1 \\
2 \\
3 \\
4 \\
5 \\
6 \\
7 \\
8\end{array}$ & $\begin{array}{l}5.55 \\
5.95 \\
5.57 \\
5.70 \\
5.90 \\
5.55 \\
5.45 \\
5.55\end{array}$ & $\begin{array}{l}1.76 \\
1.88 \\
1.76 \\
1.80 \\
1.87 \\
1.76 \\
1.72 \\
1.76\end{array}$ & $\begin{array}{l}8.50 \\
7.66 \\
2.12 \\
1.75 \\
1.10 \\
1.03 \\
0.55 \\
0.50\end{array}$ & $\begin{array}{c}0.48 \\
" \\
0.85 \\
" 1 \\
1.35 \\
" 1 \\
1.77 \\
" 17\end{array}$ & 0.95 & 2.62 & 0.82 \\
\hline B & $\begin{array}{r}1 \\
2 \\
3 \\
4 \\
5 \\
6 \\
7 \\
8 \\
9 \\
10\end{array}$ & $\begin{array}{l}7.70 \\
7.20 \\
7.75 \\
7.38 \\
7.27 \\
7.14 \\
7.88 \\
7.95 \\
7.53 \\
7.30\end{array}$ & $\begin{array}{l}1.65 \\
1.55 \\
1.66 \\
1.58 \\
1.56 \\
1.53 \\
1.69 \\
1.71 \\
1.61 \\
1.57\end{array}$ & $\begin{array}{l}7.08 \\
6.76 \\
4.50 \\
3.60 \\
1.53 \\
1.42 \\
1.12 \\
1.02 \\
0.87 \\
0.83\end{array}$ & $\begin{array}{r}0.76 \\
0.85 \\
1.19 \\
1.30 \\
1.77 \\
1 \\
2.48 \\
2.97 \\
3.17 \\
3.29\end{array}$ & 1.40 & 2.56 & 0.74 \\
\hline C & $\begin{array}{r}1 \\
2 \\
3 \\
4 \\
5 \\
6 \\
7 \\
8 \\
9 \\
10\end{array}$ & $\begin{array}{l}9.55 \\
8.79 \\
9.14 \\
9.75 \\
9.52 \\
9.85 \\
9.15 \\
9.14 \\
9.27 \\
9.25\end{array}$ & $\begin{array}{l}1.39 \\
1.28 \\
1.33 \\
1.42 \\
1.38 \\
1.43 \\
1.33 \\
1.33 \\
1.35 \\
1.34\end{array}$ & $\begin{array}{r}6.63 \\
5.75 \\
4.72 \\
3.80 \\
1.80 \\
1.58 \\
1.35 \\
1.13 \\
.50 \\
0.47\end{array}$ & $\begin{array}{l}1.77 \\
2.40 \\
3.29 \\
4.33 \\
5.58\end{array}$ & 2.06 & 2.50 & 0.65 \\
\hline
\end{tabular}


FIGURE 3 shows the correlation between $\mathrm{T} / \mathrm{To}$ and $\mathrm{QW}$, which is plotted for each of the groups $A, B$ and $C$, $i$.e. for each case that $Q$ and $H$ are same by using those figures given in TABLE 1 . From the gradient of the line, $m=-2$ is obtained.

Values for dM, h, Cpm $\gamma_{0}$, To, $\gamma \mathrm{w}$ and $\mathrm{g}$ in this experiment are as follows. $\mathrm{dM}=1 \mathrm{~mm}=1 \times 10^{-3} \mathrm{~m}$

$\mathrm{h}=3,780 \mathrm{kcal} / \mathrm{kg}$ (cedar wood with moisture content of $9 \sim 12 \%$ )

$\mathrm{Cp}=0.24 \mathrm{kcal} / \mathrm{kg}{ }^{\circ} \mathrm{C}$

$\gamma_{0}=1.161 \mathrm{~kg} / \mathrm{m}^{3}$

to $=20^{\circ} \mathrm{C}$

$\gamma_{\mathrm{w}}=998.2 \mathrm{~kg} / \mathrm{m}^{3}$

$g=9.807 \mathrm{~m} / \mathrm{s}^{2}=35.3 \times 10^{3} \mathrm{~m} / \mathrm{min}^{2}$

Consequent 1 y

$A=1.172 \times 10^{-4} \mathrm{~m}^{7} \mathrm{~min} / \mathrm{kg}^{5 / 2}$

Value for $\gamma$ was obtained from the following equations (8), [6], and (9).

$\Delta t=43.9 \times \frac{(0 \mathrm{~h} / 60)^{2 / 3}}{\mathrm{H}^{5 / 3}}$

Where

$\Delta t:$ difference between gas temperature in plume and compartment temperature ${ }^{\circ} \mathrm{C}$

$Q: \mathrm{kg} / \mathrm{min}$

$\mathrm{h}$ : kcal/kg

$\mathrm{H}: \mathrm{m}$

$\gamma\left(\mathrm{kg} / \mathrm{m}^{3}\right)=1.2931 \times \frac{273}{293+\Delta t}$

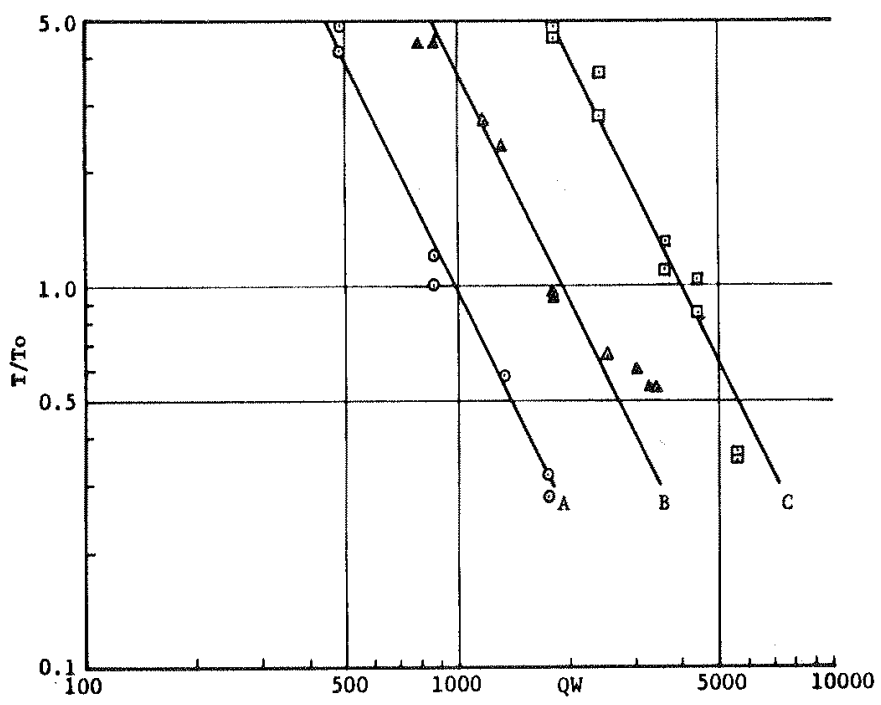

FIGURE 3 Correlation between $\mathrm{T} / \mathrm{To}$ and $\mathrm{QW}$ 


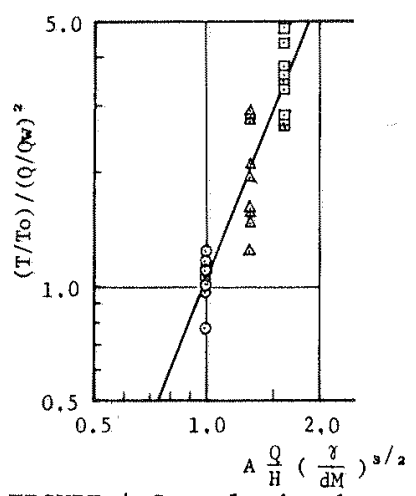

FTGURE 4 Correlation between $(\mathrm{T} / \mathrm{TO}) /(\mathrm{Q} / \mathrm{QW})^{2}$ and $\left[\mathrm{A} \cdot \frac{\mathrm{Q}}{\mathrm{H}} \cdot\left(\frac{\gamma}{\mathrm{dM}}\right)^{3 / 2}\right]$

FIGURE 4 shows the correlation between $(\mathrm{T} / \mathrm{TO}) /(\mathrm{Q} / \mathrm{QW})^{2}$ and $\left[\mathrm{A} \cdot \frac{\mathrm{Q}}{\mathrm{H}} \cdot\right.$ $\left.\left(\frac{\gamma}{d M}\right)^{3 / 2}\right]$ which is plotted by using the results and values obtained in the abovementioned experiment. From this figure and by regression analysis, $k=$ $1.05, \mathrm{n}=2.5$, and a correlation factor between the above two quantities is ca1culated to be 0.91 . Therefore, the equation ( 7 ) becomes:

$\frac{\mathrm{T}}{\mathrm{TO}}=1.05\left(\frac{\mathrm{Q}}{\mathrm{QW}}\right)^{2}\left[\mathrm{~A} \cdot \frac{\mathrm{Q}}{\mathrm{H}} \cdot\left(\frac{\gamma}{\mathrm{dM}}\right)^{3 / 2}\right]^{2 \cdot 5}$

FIGURE 5 compares the equation (10) with the results of the experiment. With the weight loss of the fuel by fire until the sprinkler actuation being $M=Q$ To, the equation (10) becomes:

$$
\begin{aligned}
\mathrm{T} & =1.05\left(\frac{\mathrm{Q}}{\mathrm{QW}}\right)^{2}\left[\mathrm{~A} \cdot \frac{\mathrm{Q}}{\mathrm{H}} \cdot\left(\frac{\gamma}{\mathrm{dM}}\right)^{3 / 2}\right]^{2.5}\left(\frac{\mathrm{M}}{\mathrm{Q}}\right) \\
& =1.05 \mathrm{~A}^{2.5} \frac{\mathrm{Q}^{3 \cdot 5} \mathrm{M}}{\mathrm{Q} \mathrm{W}^{2} \mathrm{H}^{2 \cdot 5}}\left(\frac{\gamma}{\mathrm{dM}}\right)^{3.75}
\end{aligned}
$$

where

$T$ : time from sprinkler actuation to fire extinguishment min

$A=\frac{h}{C p \gamma_{0} \text { to } \gamma \mathrm{w}^{3 / 2} \mathrm{~g}^{1 / 2}} \quad \mathrm{~m}^{7} \mathrm{~min} / \mathrm{kg}^{5} / 2$

$\mathrm{h}$ : heat release rate per unit weight of fuel $\mathrm{kcal} / \mathrm{kg}$

Cp: isopiestic specific heat of air $0.24 \mathrm{kcal} / \mathrm{kg}{ }^{\circ} \mathrm{C}$

ro: density of air under standard ambient condition $\left(20^{\circ} \mathrm{C}, 1 \mathrm{~atm}.\right) 1.161 \mathrm{~kg} / \mathrm{m}^{3}$

to: temperature of air under standard ambient condition $\left(20^{\circ} \mathrm{C}\right.$, I atm. $20^{\circ} \mathrm{C}$

$\gamma_{w}$ : density of water $998.2 \mathrm{~kg} / \mathrm{m}^{3}$

$\mathrm{g}$ : gravitational acceleration $35.3 \times 1.0^{3} \mathrm{~m} / \mathrm{min}^{2}$

$\mathrm{Q}$ : mass burning rate before sprinkler actuation $\mathrm{kg} / \mathrm{min}$

Qw: water delivery rate onto upper surface of fuel $\mathrm{kg} / \mathrm{min}$

$\mathrm{M}$ : weight loss of fuel until sprinkler actuation $\mathrm{kg}$

$\mathrm{H}$ : distance from upper surface of fuel to ceiling surface $\mathrm{m}$

$\gamma$ : density of gas in plume

dM: mean diameter of spray drops

$\mathrm{kg} / \mathrm{m}^{3}$

$\mathrm{m}$

It is now possible to calculate the time from the sprinkler actuation to fire extinguishment by the equation(11). 


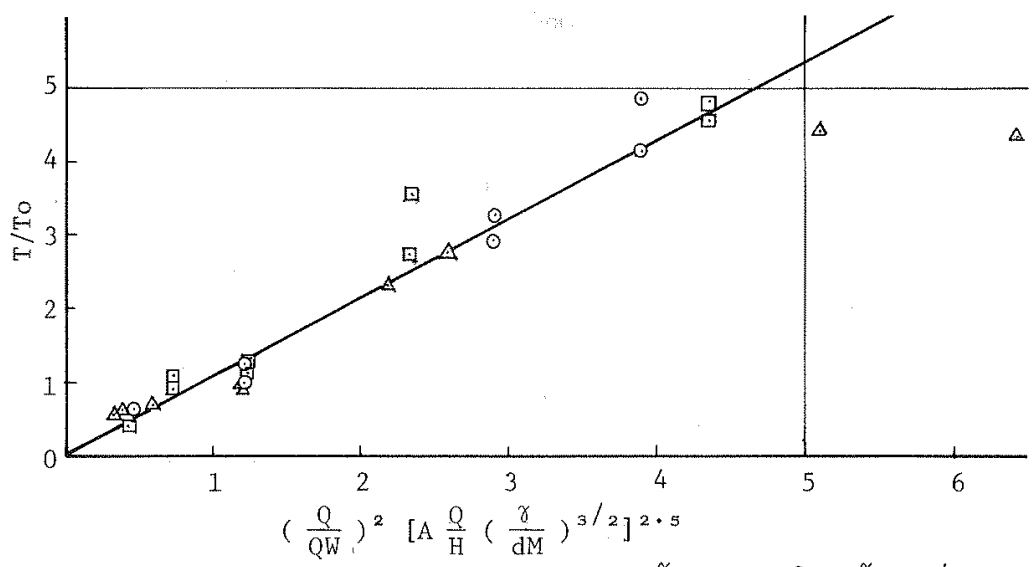

FIGURE 5 Correlation between $T /$ To and $\left(\frac{\gamma}{Q W}\right)^{2}\left[A \frac{Q}{H}\left(\frac{\gamma}{d M}\right)^{3 / 2}\right]^{2 \cdot 5}$

\section{NUMERTCAL CALCULATION}

Here, a crib fire burning at a constant rate is used as fire model and sprinkler actuation time and fire extinguishing time are calculated. Four sprinklers are mounted on the celling of a very large room and on a spacing of $3.25 \mathrm{~m}$ in a cross pattern. The crib is located in the center of the four sprinklers and with a distance of $2.5 \mathrm{~m}$ from the celling to the upper surface of the crib. Therefore, the horizontal distance from the center of the crib to sprinklers is $2.3 \mathrm{~m}$.

The temperature rise of gas at the ceiling, $\Delta T g$, and velocity, $u$, are obtained from the following equation [6].

$$
\begin{aligned}
\Delta \mathrm{Tg} & =\frac{14 \dot{\mathrm{Q}}^{2 / 3}}{\mathrm{Hr} \mathrm{r}^{2 / 3}}\left[{ }^{\circ} \mathrm{C}\right] \\
u & =\frac{0.32 \dot{\mathrm{Q}}^{1 / 3} \mathrm{H}^{1 / 2}}{\mathrm{r}^{5 / 6}}[\mathrm{~m} / \mathrm{s}]
\end{aligned}
$$

where

$r$ : horizontal distance from center of crib in

$H:$ distance between upper surface of $\mathrm{crib}$ and ceiling $\mathrm{m}$
$\dot{\mathrm{Q}}:$ heat release rate
$\mathrm{kcal} / \mathrm{s}$

$\mathrm{kca1} / \mathrm{s}$

Using these equations, gas temperature and velocity at the sprinklers are calculated for each of three cribs with six, eight and ten layers of wood sticks as shown in FIGURE 2. TABLE 2 shows results of the calculations. In this case the heat release rate was calculated with the heat release rate per unit weight of wood as being $3,870 \mathrm{kcal} / \mathrm{kg}$. The sprinkler model discussed in this paper is to be the one we used for this experiment (i.e. model MHS-12B manufactured by Nohmi Bosai Kogyo Co., Ltd.). The sprinkler has a rated operating temperature of $72^{\circ} \mathrm{C}$, and the relation between the time constant $\tau$, and air velocity, $u$, is expressed by the following equation.

$\tau=2.32 u^{-0.66}[\tau: \min , u: m / s]$ 
TABLE 2. Sprinkler actuation time in fire models

\begin{tabular}{|c|c|c|c|}
\hline Number of layers of crib & 6 & 8 & 10 \\
\hline $\begin{array}{l}\text { Mass burning rate } \\
(\mathrm{kg} / \mathrm{min} .)\end{array}$ & 0.95 & 1.40 & 2.06 \\
\hline $\begin{array}{l}\text { Heat release rate } \\
{[\dot{0}](\mathrm{kcal} / \mathrm{s})}\end{array}$ & 61.3 & 90.3 & 132.9 \\
\hline $\begin{array}{l}\text { Distance from upper surface } \\
\text { of crib to ceiling [H] (m) }\end{array}$ & \multicolumn{3}{|c|}{2.5} \\
\hline $\begin{array}{l}\text { Horizontal distance between } \\
\text { crib and sprinkler [r] (m) }\end{array}$ & \multicolumn{3}{|c|}{2.3} \\
\hline $\begin{array}{l}\text { Rise in actuation temperature } \\
\text { above ambient }[\Delta \mathrm{T} \mathrm{T}] \quad\left({ }^{\circ} \mathrm{C}\right)\end{array}$ & \multicolumn{3}{|c|}{$52(72-20)$} \\
\hline $\begin{array}{l}\text { Rise in gas temperature at sprinkler } \\
\text { location above ambient }\left[\Delta \mathrm{T}^{\prime} \mathrm{g}\right]\left({ }^{\circ} \mathrm{C}\right)\end{array}$ & 50 & 65 & 84 \\
\hline $\begin{array}{l}\text { Gas temperature at sprinkler } \\
\text { location }\left({ }^{\circ} \mathrm{C}\right)\end{array}$ & 70 & 85 & 104 \\
\hline $\begin{array}{l}\text { Fow velocity at sprinklex } \\
\text { location on ceiling }(\mathrm{m} / \mathrm{s})\end{array}$ & 1.0 & 1.1 & 1.3 \\
\hline $\begin{array}{l}\text { Time constant of sprinkler } \\
\text { (min.) }\end{array}$ & 2.32 & 2.18 & 1.95 \\
\hline $\begin{array}{l}\text { Actuation time of sprinkler } \\
\text { (min.) }\end{array}$ & & 3.51 & 1.88 \\
\hline
\end{tabular}

Generally the actuation time, tr, of the sprinkler exposed to air current with a constant temperature is expressed by the following equation.

$\operatorname{tr}=-\tau \ln (1-\Delta \mathrm{Ta} / \Delta \mathrm{Tg})$

Where

$\tau$ : time constant of sprinkler

$\Delta \mathrm{Ta}:$ difference between initial temperature $\left(20^{\circ} \mathrm{C}\right)$ of 1 ink and actuation temperature

$\Delta \mathrm{Tg}$ : difference between initial temperature $\left(20^{\circ} \mathrm{C}\right)$ of 1 ink and gas temperature

TABLE 2 shows sprinkler actuation time for each of the fire models obtained from the equations (14) and (15). From this table it can be seen that with the 6-layer crib fire the gas temperature at the sprinkler does not reach the operating temperature, and consequently the sprinkler is not actuated. 
TABLE 3. Extinguishing time in fire models

\begin{tabular}{|c|c|c|c|}
\hline \multicolumn{2}{|c|}{ Number of layers of crib } & 8 & 10 \\
\hline \multicolumn{2}{|c|}{$\begin{array}{l}\text { Mass burning rate } \\
(\mathrm{kg} / \mathrm{min} .)\end{array}$} & 1.40 & 2.06 \\
\hline \multirow{4}{*}{$\begin{array}{l}\text { Water } \\
\text { discharge rate } \\
{[Q]} \\
\text { (kg/min.) }\end{array}$} & 1 sprinklex & \multicolumn{2}{|c|}{0.76} \\
\hline & $2 \quad n$ & \multicolumn{2}{|c|}{1.52} \\
\hline & $3 \quad 1$ & \multicolumn{2}{|c|}{2.28} \\
\hline & $4 \quad 1$ & \multicolumn{2}{|c|}{3.04} \\
\hline \multicolumn{2}{|c|}{$\begin{array}{l}\text { Distance from upper surface } \\
\text { of crib to ceiling [H] (m) }\end{array}$} & \multicolumn{2}{|c|}{2.5} \\
\hline \multicolumn{2}{|c|}{$\begin{array}{l}\text { Mean diameter of spray drops } \\
{[\mathrm{dM}](\mathrm{m})}\end{array}$} & \multicolumn{2}{|c|}{$1 \times 10^{-3}$} \\
\hline \multicolumn{2}{|c|}{$\begin{array}{l}\text { Density of air in plume } \\
{[\gamma] \quad\left(\mathrm{kg} / \mathrm{m}^{3}\right)}\end{array}$} & 0.47 & 0.65 \\
\hline \multicolumn{2}{|c|}{$\begin{array}{l}\text { Fuel weight loss at sprinkler } \\
\text { actuation }[M] \quad(\mathrm{kg})\end{array}$} & 4.91 & 3.87 \\
\hline \multirow{4}{*}{$\begin{array}{l}\text { Extinguishing } \\
\text { time } \\
\text { [T] } \\
\text { (min.) }\end{array}$} & 1 sprinkler & $\underline{-1}$ & $=$ \\
\hline & 2 & 6.27 & - \\
\hline & 3 & 2.79 & 5.22 \\
\hline & $4 \quad 11$ & 1.57 & 2.93 \\
\hline
\end{tabular}

Note: Calculated time of extinguishment more than (5 $\mathrm{x}$ actuation time) is not listed because there is no such time in our experiment.

With a discharge pressure of $1 \mathrm{~kg} / \mathrm{cm}^{2}$ the sprinkler has a water density of $2.1 \mathrm{l} / \mathrm{m}^{2} / \mathrm{min}$. $(0.76 \mathrm{~kg} / \mathrm{min}$ on the crib of $0.6 \mathrm{~m} \times 0.6 \mathrm{~m})$ measured at the position of a vertical distance of $2.5 \mathrm{~m}$ and a horizontal distance of $2.3 \mathrm{~m}$ from the sprinkler, and its mean diameter of water drops is $1 \mathrm{~mm}$. Using these data and values given in TABLE 2, calculation of extinguishing time for each of the fire models was made by the equation (11) with respect to the both cases that only one sprinkler is actuated and two to four sprinklers are actuated simultaneously, results of which are shown in TABLE 3. In this case the weight loss of the fuel until actuation of the sprinkler, $\mathrm{M}(\mathrm{kg})$, was determined to be a product of the sprinkler actuation time and the mass burning rate (constant). 


\section{CONCLUSION}

When sprinkler are used for the purpose of reducing physical damage, whether they will be capable of successfully extinguishing fires, and to what extent they will be able to suppress the burning loss until fires are extinguished are matters of our great concern. Nevertheless, it is of utmost importance that sprinklers used in houses, hotels, wards in hospitals etc., are capable of quickly responding to and extinguish fires from the viewpoint of assuring the safety of evacuation. Therefore, we consider that the extinguishing time for sprinklers will become one of the important factors as index for extinguishing effectiveness of sprinklers in the future.

\section{ACKNOWLEDGMENTS}

Dr. K. Akita, former professor of Tokyo University, has given advices on this study. The members of Laboratory of Nohmi Bosai Kogyo Co,, LTD. have conducted the experiments. The auther would like to thank them for their kindness.

\section{REFERENCES}

1. Heskestad, G., Delichatsios M. A., Enviromment of Fire Detectors-Phase 1 : Effect of Fire Size, Ceiling Height and Material, Volume 2. Analysis, NBSGCR-77-95, National Bureau of Standards, July 1977

2. Evans, David D., Calculating Sprinkler Actuation Time in Compartments, Society of Fire Protection Engineers Symposium, Computer Application in Fire Protection : Analysis, Modeling and Design, March 1984

3. Heskestad, G., Sprinkler Performance as related to Size and Design, Volume I -Laboratory Investigation, FMRC No.22437, Factory Mutual Research, February 1979

4. Kung, H. C., Hi11, J. P., Extinction of Wood Crib and Pa11et Fires, Combustion and Flame, Vol.24, June 1975

5. Akita, K., Study of Evaporation of Water Drops Falling down through the Air of High Temperature, Report of Fire Research Institute, Volume 3, No.4 March 1953 (in Japanese)

6. Alpert, R. L., Calculation of Response Time of Ceiling-Mounted Fire Detectors, Fire Technology, August 1972 